\title{
Improvement of Lipid Profile and Antioxidant Status of Hyperlipidemic Albino Rats by Gamma-irradiated Safflower (Carthamus tinctorius L.)
}

\section{R. G. Hamza and M. F. Farag}

Food Irradiation Research Dept., National Centre for Radiation Research and Technology (NCRRT), P. O. Box: 29 Nasr City, Cairo, Egypt.

\begin{abstract}
UYPER-LIPIDEMIA is a dominant risk factor that contributes to the development and progression of atherosclerosis. Safflower is rich in the essential omega- 6 and omega-3 polyunsaturated fatty acids and phenolic compounds which are known to be effective for the treatment of hyperlipidemia. This study was performed to examine the efficacy of safflower to ameliorate the induced hyper-lipidemia in rats.

The results obtained revealed that rats fed on high fat diet (HFD) significantly induced an increase in lipid profile, glucose and some liver enzymes as well as elevation of malondialdehyde (MDA) associated with a significant decrease in high density lipoprotein (HDL-C), glutathione (GSH) content and some antioxidant enzymes activity. However, when rats received HFD containing either raw or irradiated safflower (1\% w/w), a significant improvement in the above mentioned parameters was seen. In conclusion, safflower supplementation in diet of rats pointed out to a promising role of safflower, a natural product, on antioxidant enzymes, liver function and lipid profile of hyper-lipidemic rats, regardless if it is irradiated or not.
\end{abstract}

Keywords: Safflower, fat diet, lipid profiles, antioxidants, $\gamma$-rays.

Long-lasting high-fat diet causes the reduction of the activity of hepatic lipase and lipoprotein lipase and other lipid metabolic enzymes, leads to lipid metabolism disturbance and hyper-lipidemia (Lin et al., 2005 and Li et al., 2011). Hyper-lipidemia is a dominant risk factor that contributes to the development and progression of atherosclerosis which is the main reason for coronary heart disease, hypertension and cerebrovascular disease (Zhang et al., 2011 and Herrera et al., 2011). 
The use of functional foods rich in polyunsaturated or monounsaturated fats in diets aimed to lowering plasma cholesterol levels, reducing the risk of coronary heart disease and preventing or treating many chronic diseases (Moon et al., 2001). In addition, epidemiological studies have shown inverse relationships between consumption of diets rich in polyphenols and the cardiovascular risk. Much evidence indicates that the increased oxidative stress, such as oxidative modification of LDL, is deeply involved in the development of atherogenesis. So, it seems reasonable to attribute the cardioprotective effect of dietary polyphenols to their potent antioxidant activity (Halliwell et al., 2005).

Carthamus tinctorius $L$. has been grown for centuries, primarily for its colourful petals to use as a food colouring and flavouring agent (Esendal, 2001). It has attracted significant interest as it is rich in the essential n-6 polyunsaturated fatty acid (PUFA) linoleic acid and n-3 $\alpha$-linolenic acid. Numerous health organizations have recommendations for dietary linoleic acid intake, generally falling within the range of $3-10 \%$ of total energy consumption (Harris et al., 2009 and Asp et al., 2011). Several studies postulated that safflower flower is impressive for the treatment of inflammation, hyper-lipemia, arteriosclerosis, and osteoporosis, promoting blood coagulation, normalizing menstruation, and eliminating blood stasis (Zhao et al., 2009).

Food irradiation has been recognized as a reliable and safe method for the preservation of food and for improving the hygienic quality and nutritional value of food (Al-Kaisey et al., 2002). In addition to the control of microorganisms of numerous food commodities, ionizing irradiation can be used to reduce several carcinogenic agents (Fan and Mastovska, 2006).

Thus, the present study was designed to evaluate the possible beneficial effect of raw and irradiated safflower on serum lipid parameters and antioxidant enzymes in albino rats fed on fat-rich diet.

\section{Material and Methods}

\section{Material}

Safflower flower and standard commercial rodent diet were purchased from local herbal market (Cairo, Egypt). The Safflower was crushed to coarse powder and sieved through No. 20 mesh size.

Egypt. J. Rad. Sci. Applic., Vol. 24, No. 2 (2011) 


\section{High fat diet}

HFD (20g fat/ $100 \mathrm{~g}$ diet): A wt of $20 \mathrm{~g}$ fat (a mixture of $19 \mathrm{~g}$ butter oil and $1 \mathrm{~g}$ soybean oil) (Woods et al., 2002) was added to $100 \mathrm{~g}$ control diet.

\section{Irradiation process}

Powder of safflower was transferred into polyethylene bags and treated with $10 \mathrm{kGy}$ of gamma rays, using a ${ }^{60} \mathrm{Co}$ source at a dose rate of $4.75 \mathrm{kGy} / \mathrm{h}$ at NCRRT, Cairo, Egypt.

\section{Fatty acids determination}

Total fatty acid (FA) concentrations in Safflower flower were determined according to Kinsella (1966).

\section{Animals}

The current experiments were conducted on male albino rats $(150 \pm 20 \mathrm{~g})$. The animals were housed under conditions of controlled temperature $\left(30 \pm 2^{\circ} \mathrm{C}\right)$ with natural light. Food and water were provided ad-libitum.

\section{Experimental design}

The animals were randomly divided into four groups, each consisted of 7 rats. Group 1: rats were fed on normal diet for 10 weeks, served as a control, group 2: rats were fed on HFD for 10 weeks and group 3-4: rats were fed on HFD supplemented with $1 \%$ of either raw or $\gamma$-irradiated safflower powder. At the end of the experimental period, the rats in each group were fasted overnight, anaesthetized with diethyl ether and sacrificed. Blood samples were collected by heart puncture, allowed to coagulate and centrifuged to obtain serum for biochemical analysis.

\section{Biochemical Analysis}

Total lipids (TL), total cholesterol (TC), triglycerides (TG) and HDL-C were determined according to the procedure described by Frings et al. (1972), Allain et al. (1974), Fossati and Prencipel (1982) and Demacker et al. (1980), respectively. Low-density lipoprotein-cholesterol (LDL-C), very Low-density lipoprotein-cholesterol (vLDL-C) and atherogenic index were evaluated 
according to Friedwald et al. (1972), Norbert (1995) and Harnafi et al. (2008) formulas, respectively by the following equations: LDL-C $(\mathrm{mg} / \mathrm{dl})=\mathrm{TC}-$ $(\mathrm{TG} / 5+\mathrm{HDL}-\mathrm{C}), \mathrm{vLDL}-\mathrm{C}(\mathrm{mg} / \mathrm{dl})=\mathrm{TG} / 5$ and the Ath. Index $=(\mathrm{TC}-\mathrm{HDL}-\mathrm{C}) /$ HDL-C. Serum glucose was evaluated by the method of Trinder (1969). The activity of serum aspartate transaminase (AST) and alanine transaminase (ALT) were assayed by the method of Reitman and Frankel (1957) while serum alkaline phosphatase activity (ALP) was assessed according to Kind and King (1954). MDA was determined by the method of Yoshioka et al. (1979). EDTA was used as anticoagulant for blood samples required to estimate GSH according to Gross et al. (1967). Catalase (CAT) activity was estimated by the method of Bergmeyer and Grabe (1987) and superoxide dismutase (SOD) was measured by using the method of Minami and Yoshikawa (1979).

\section{Statistical analysis}

Statistical analyses were performed using computer program Statistical Packages for Social Science (SPSS, 1998), and values compared with each other using suitable tests.

\section{Results}

The data showed that the main unsaturated fatty acids of raw safflower were linoleic (33.37\%) and linolenic (4.78\%) of total identified fatty acids.

The total saturated fatty acids (SFA) and total unsaturated fatty acids (USFA) were 0.72 and $40.56 \%$ respectively, while in irradiated sample were 0.77 and $40.62 \%$ respectively. The total omega- 6 fatty acids and total omega-3 fatty acids of raw safflower were (33.53 and 6.63\%) while of $\gamma$-irradiated safflower were (33.85 and 6.40\%).

The animals maintained on the HFD showed a significant high value of serum TL, TG, TC, LDL-C, vLDL-C and atherogenic index associated with a significant reduction in serum HDL-C compared to those of control animals. In comparison with rats fed HFD, the animals received the HFD fortified with either raw or $\gamma$-irradiated safflower revealed a significant decrease in the various measurements of lipids in serum, except the HDL-C which was significantly increased (Table 2).

Egypt. J. Rad. Sci. Applic., Vol. 24, No. 2 (2011) 
TABLE 1. Fatty acid composition of raw and $\gamma$-irradiated safflower.

\begin{tabular}{|l|c|c|}
\hline \multicolumn{1}{|c|}{ Fatty acids } & \% raw & \% irradiated \\
\hline Myristic (14:0) & 0.04 & 0.05 \\
\hline Palmitic (16:0) & 0.05 & 0.05 \\
\hline Palmitolic (16:1) & 0.08 & 0.07 \\
\hline Stearic (18:0) & 0.32 & 0.36 \\
\hline Oleic (18:1) & 0.32 & 0.30 \\
\hline Linoleic (18:2) & 33.37 & 33.68 \\
\hline Linolenic (18:3) & 4.78 & 4.63 \\
\hline Arachidic (20:0) & 0.12 & 0.09 \\
\hline Arachidonic (20:4) & 0.16 & 0.17 \\
\hline Eicosapentanoic (20:5) & 0.20 & 0.19 \\
\hline Behenic (22:0) & 0.15 & 0.17 \\
\hline Docosahexaenoic (22:6) & 1.65 & 1.58 \\
\hline Lignoceric (24:0) & 0.04 & 0.05 \\
\hline Total SFA & 0.72 & 0.77 \\
\hline Total UFA & 40.56 & 40.62 \\
\hline Total MUFA & 0.40 & 0.37 \\
\hline Total PUFA & 40.16 & 40.25 \\
\hline n-6 & 33.53 & 33.85 \\
\hline n-3 & 6.63 & 6.40 \\
\hline n-6/n-3 & 5.06 & 5.29 \\
\hline Others & 58.72 & 58.61 \\
\hline Tolat & & \\
\hline
\end{tabular}

Total MUFA: Total mono unsaturated fatty acids.

Total n-6: Total omega- $6=(\mathrm{C} 18: 2+\mathrm{C} 20: 4)$.

Total n-3: Total omega-3= $(\mathrm{C} 18: 3+\mathrm{C} 20: 5+\mathrm{C} 22: 6)$.

TABLE 2. Effect of feeding rats on HFD enriched with either raw or $\gamma$-irradiated safflower on serum lipid profiles.

\begin{tabular}{|c|c|c|c|c|c|c|c|}
\hline $\begin{array}{l}\text { Animal } \\
\text { groups }\end{array}$ & $\begin{array}{c}\mathbf{T L} \\
\mathrm{mg} / \mathrm{dl}\end{array}$ & $\begin{array}{c}\mathbf{T C} \\
\mathrm{mg} / \mathrm{dl}\end{array}$ & $\begin{array}{c}\mathbf{T G} \\
\mathrm{mg} / \mathrm{dl}\end{array}$ & $\begin{array}{c}\text { HDL-C } \\
\mathrm{mg} / \mathrm{dl}\end{array}$ & $\begin{array}{c}\text { LDL-C } \\
\mathrm{mg} / \mathrm{dl}\end{array}$ & $\begin{array}{c}\mathbf{v - L D L} \\
\mathrm{mg} / \mathrm{dl}\end{array}$ & $\begin{array}{l}\text { Ath. } \\
\text { index }\end{array}$ \\
\hline Control & $\begin{array}{c}494.35 \\
\pm 15.11^{\mathrm{a}} \\
\end{array}$ & $\begin{array}{r}119.22 \\
\pm 6.62^{\mathrm{a}} \\
\end{array}$ & $\begin{array}{r}112.21 \\
\pm 7.68^{\mathrm{a}} \\
\end{array}$ & $\begin{array}{c}51.24 \\
\pm 5.46^{\mathrm{a}} \\
\end{array}$ & $\begin{array}{c}45.52 \\
\pm 6.14^{\mathrm{a}} \\
\end{array}$ & $\begin{array}{c}22.44 \\
\pm 0.56^{\mathrm{a}} \\
\end{array}$ & $\begin{aligned} & 1.33 \\
& \pm 0.11^{\mathrm{a}} \\
&\end{aligned}$ \\
\hline HFD & $\begin{array}{l}864.11 \\
\pm 6.45^{c} \\
\end{array}$ & $\begin{array}{r}177.61 \\
\pm 9.72^{c} \\
\end{array}$ & $\begin{array}{r}220.11 \\
\pm 9.26^{c} \\
\end{array}$ & $\begin{array}{c}32.91 \\
\pm 4.56^{c} \\
\end{array}$ & $\begin{array}{r}100.68 \\
\pm 6.32^{c} \\
\end{array}$ & $\begin{array}{r}44.02 \\
\pm 0.83^{c} \\
\end{array}$ & $\begin{array}{r}4.39 \\
\pm 0.23^{c} \\
\end{array}$ \\
\hline $\begin{array}{c}\text { HFD+ } \\
\text { Saff. }\end{array}$ & $\begin{array}{r}673.31 \\
\pm 5.93^{\mathrm{b}} \\
\end{array}$ & $\begin{array}{r}137.68 \\
\pm 6.19^{\mathrm{b}} \\
\end{array}$ & $\begin{array}{r}177.52 \\
\pm 6.94^{\mathrm{b}} \\
\end{array}$ & $\begin{array}{r}45.88 \\
\pm 5.55^{\mathrm{b}} \\
\end{array}$ & $\begin{array}{r}56.30 \\
\pm 4.36^{\mathrm{b}} \\
\end{array}$ & $\begin{array}{r}35.50 \\
\pm 0.48^{\mathrm{b}} \\
\end{array}$ & $\begin{array}{r}2.00 \\
\pm 0.13^{b} \\
\end{array}$ \\
\hline $\begin{array}{c}\text { HFD+ } \\
\text { irr.Saff. }\end{array}$ & $\begin{array}{l}661.37 \\
\pm 7.81^{\mathrm{b}}\end{array}$ & $\begin{array}{r}134.48 \\
\pm 5.66^{\mathrm{b}}\end{array}$ & $\begin{array}{r}171.23 \\
\pm 6.47^{\mathrm{b}}\end{array}$ & $\begin{array}{l}45.13 \\
\pm 4.9^{\mathrm{b}}\end{array}$ & $\begin{array}{c}55.11 \\
\pm 4.47^{\mathrm{b}}\end{array}$ & $\begin{array}{c}34.25 \\
\pm 0.41^{\mathrm{b}}\end{array}$ & $\begin{array}{c}1.98 \\
\pm 0.17^{\mathrm{b}}\end{array}$ \\
\hline
\end{tabular}

Values are expressed as means \pm S.E. $(n=7)$.

Values in the same column with different superscripts are differing significantly at $P<0.05$.

$\mathrm{HFD}=$ high fat diet, Saff. = Safflower, irr. Saff. = irradiated Safflower.

Egypt. J. Rad. Sci. Applic., Vol. 24, No. 2 (2011) 
The results recorded in Table 3 exhibited a significant elevation in AST, ALT, and ALP level as well as glucose concentration in HFD group compared with those of control and all treated groups. While a significant depression in liver function enzymes and glucose levels was observed in treated rats as compared to HFD group.

TABLE 3. Effect of feeding rats on HFD enriched with either raw or $\gamma$-irradiated safflower on glucose level and liver enzymes activity.

\begin{tabular}{|l|c|c|c|c|}
\hline \multicolumn{1}{|c|}{ Animal groups } & $\begin{array}{c}\text { Glucose } \\
\mathrm{mg} / \mathrm{dl}\end{array}$ & $\begin{array}{c}\text { ALP } \\
\mathrm{U} / \mathrm{L}\end{array}$ & $\begin{array}{c}\text { ALT } \\
\mathrm{U} / \mathrm{ml}\end{array}$ & $\begin{array}{c}\text { AST } \\
\mathrm{U} / \mathrm{ml}\end{array}$ \\
\hline Control & $88.17 \pm 5.53^{\mathrm{a}}$ & $81.64 \pm 4.28^{\mathrm{a}}$ & $13.52 \pm 0.57^{\mathrm{a}}$ & $23.93 \pm 1.12^{\mathrm{a}}$ \\
\hline HFD & $186.58 \pm 6.07^{\mathrm{c}}$ & $144.05 \pm 5.14^{\mathrm{c}}$ & $29.08 \pm 1.07^{\mathrm{c}}$ & $50.84 \pm 2.17^{\mathrm{c}}$ \\
\hline HFD+ Saff. & $100.45 \pm 2.56^{\mathrm{b}}$ & $101.51 \pm 6.25^{\mathrm{b}}$ & $18.89 \pm 1.46^{\mathrm{b}}$ & $30.82 \pm 1.28^{\mathrm{b}}$ \\
\hline HFD+ irr. Saff. & $102.57 \pm 2.73^{\mathrm{b}}$ & $98.80 \pm 4.93^{\mathrm{b}}$ & $18.35 \pm 0.65^{\mathrm{b}}$ & $30.71 \pm 1.42^{\mathrm{b}}$ \\
\hline
\end{tabular}

Legends as in Table 2 .

Due to keeping rats on HFD, a significant increase in MDA as well as a remarkable reduced level of GSH and activity of SOD and CAT was noticed as compared with those of rats received control diet (Table 4). In contrast, giving rats HFD plus raw or $\gamma$-irradiated safflower caused a significant decreased level of MDA and significant elevated concentration of GSH, SOD and CAT activity.

TABLE 4. Effect of feeding rats on HFD enriched with either raw or $\gamma$-irradiated safflower on MDA, GSH, CAT and SOD activity.

\begin{tabular}{|l|c|c|c|c|}
\hline \multicolumn{1}{|c|}{ Animal groups } & $\begin{array}{c}\text { MDA } \\
\mathrm{n} \mathrm{mol} / \mathrm{ml}\end{array}$ & $\begin{array}{c}\text { GSH } \\
\mathrm{mg} / \mathrm{dl}\end{array}$ & $\begin{array}{c}\text { SOD } \\
\mathrm{u} / \mathrm{ml}\end{array}$ & $\begin{array}{c}\text { CAT } \\
\mathrm{u} / \mathrm{ml}\end{array}$ \\
\hline Control & $68.40 \pm 6.56^{\mathrm{a}}$ & $62.61 \pm 4.5^{\mathrm{a}}$ & $5.78 \pm 0.65^{\mathrm{a}}$ & $37.66 \pm 2.45^{\mathrm{a}}$ \\
\hline HFD & $129.51 \pm 9.12^{\mathrm{c}}$ & $44.51 \pm 4.28^{\mathrm{c}}$ & $4.17 \pm 0.41^{\mathrm{c}}$ & $22.58 \pm 3.18^{\mathrm{c}}$ \\
\hline HFD+ Saff. & $80.03 \pm 7.15^{\mathrm{b}}$ & $57.15 \pm 5.7^{\mathrm{b}}$ & $5.51 \pm 0.38^{\mathrm{b}}$ & $33.62 \pm 3.67^{\mathrm{b}}$ \\
\hline HFD+ irr. Saff. & $79.23 \pm 5.68^{\mathrm{b}}$ & $58.17 \pm 4.35^{\mathrm{b}}$ & $5.58 \pm 0.43^{\mathrm{b}}$ & $33.74 \pm 2.8^{\mathrm{b}}$ \\
\hline
\end{tabular}

\section{Discussion}

High-fat intake has been shown to play a relevant part in the obesity epidemic and it is considered as one of the most important risk factors involved in different diseases (Herrera et al., 2011) such as cardiovascular disease and insulin resistance and diabetes. (Buettner et al., 2007). Safflower and its major and unique phenolic constituents, serotonin hydroxycinnamic acid amides (serotonin derivatives), essential n-6 linoleic acid and n-3 $\alpha$ - linolenic acid, were documented to be protective against LDL oxidation and atherogenesis (Koyama et al., 2006).

Egypt. J. Rad. Sci. Applic., Vol. 24, No. 2 (2011) 
Results occurred in Table 1. point to the fatty acid composition of both raw and irradiated safflower which in agreement with those deduced by Zahran et al. (2007). No real effect of gamma-irradiation at dose $10 \mathrm{KGy}$ on the chemical constituents (Abdel-Khalek, 2008). The content of fatty acid did not change in the range of dose under study. These observations concord with those of (Oraei et al., 2011) who studied the effect of gamma-irradiation on the major fatty acids (oleic, linoleic, Linolenic, palmitic, stearic) and found no effect of $\gamma$-irradiation on major fatty acid composition.

In the present study, rats fed HFD have higher concentration of TL, TC, TG, LDL-C, vLDL-C and Ath. index accompanied by lower level of HDL-C than those consumed control diet (Table 2). Younies (2008) reported that HFD induced a significant rise in TL, TC, TG, LDL-C and Ath. index while a significant decline was recorded in serum HDL-C. Hyper-lipidemia is a result of an oxidative abuse due to free radicals formed by the interaction of HFD (Shyamala et al., 2005). The effect of HFD in this study, on the lipid profile, was in coincidence with the previous study of Hamza and Mahmoud (2009). Ji and Gong (2008) declared significant increment in plasma TG, phospholipids and TC of rats fed on HFD. However, HDL-C showed a distinct diminution in plasma of HFD animals, versus the control group.

As shown in this experiment, rats fed HFD supplemented with raw or $\gamma$-irradiated safflower have lower concentration of TL, TC, TG, LDL-C, vLDL-C and atherogenic index and higher level of HDL-C than the rats fed on HFD only. Several hypotheses have been advanced for the cholesterol-lowering effect of safflower rich in PUFAs, including the stimulation of cholesterol excretion into the intestine and oxidation of cholesterol to bile acids (Gotto et al., 1990). Moreover, this cholesterol-lowering effect may be as a consequence of a shift in distribution of cholesterol from the plasma into the tissues because of increased catabolic rate of LDL-C due to up-regulation of LDL receptor by PUFAs and down-regulation by saturated fatty acids (Spady et al., 1993).

Omega-3 PUFA ( $\alpha$ - linolenic acid) content of safflower can reduce TG concentration through the inhibition of hepatic vLDL-TG synthesis and secretion that is secondary to a decrease in TG synthesis. This decrease in vLDL-TG secretion may be due to the decrease in the expression of hepatic 
gene transcription factor sterol regulatory element binding proteins (SREBP-1c) which is the key switch in controlling lipogenesis, (Asp et al., 2011).

The enzymatic activity seen in Table 3. indicated that AST, ALT and ALP values were elevated in the serum of the HFD fed rats. This could be owing to leakage of the enzymes into the serum as a result of damage to the integrity of the heart and liver. Elevated serum activity of these enzymes has been reported to be indicators of calculated risk of cardiovascular disease, Otunola et al. (2010). Addition of raw or $\gamma$-irradiated safflower to HFD caused a significant decline in the activity of liver enzymes. A possible mechanism of the reduced activity of the tested enzymes and the hepatoprotective effect of safflower may be related to its antioxidant effect because of the phenolic and flavonoids compounds (Kim et al., 2007). Previous study allowed that polyphenols can inhibit nitrosation and that flavonoids have a hepatoprotective activity (Orhan $e t$ al., 2007).

It could be noticed that glucose level increased in serum of HFD fed rats (Table 3). HFD would induce free radical production which induced oxidative stress. A relationship between glucose concentration and oxidative stress has been shown in red blood cells (Deladino et al., 2008). Raw or $\gamma$-irradiated safflower significantly lowered serum glucose concentration suggesting its glucose lowering property and the hypoglycemic effect of its phenolic content and isoflavones (Kim et al., 2007).

In the present study it has been found that MDA was significantly increased in rats fed HFD, compared to those fed normal diet. However, GSH content and SOD and CAT activity reflected a significant reduction (Table 4). These results are consistent with those reported by Shyamala et al. (2005), so, elevated level of MDA of HFD rat due to the excessive formation of free radicals and activation of lipid peroxidation system. Most studies provided evidence of increased TBARS level in the myocardium of hyper-lipidemic rabbits (Lapenna et al., 1992), while decreased GSH content in the tested organs of mice fed with high-fat was pronounced (Ming et al., 2009).

Raw or $\gamma$-irradiated safflower supplementation along with HFD reduced lipid peroxidation in the body as shown by the reduction in MDA level and enhances the antioxidant status as denoted by increasing GSH content and SOD Egypt. J. Rad. Sci. Applic., Vol. 24, No. 2 (2011) 
and CAT activity. The effects of safflower are regarded to safflower polyphenols which composed of flavones, lignin, and serotonin derivatives. These phenolic compounds have radical scavenging activity and inhibit lipid peroxidation (Barnes, 2010 and Kim et al., 2007). Furthermore, Lee et al. (2003) reported that $80 \mathrm{mg}$ isoflavones/day decreased plasma malondialdehyde and increased total antioxidant status in hyper-cholesterolemic postmenopausal women. Linoleic, as a major fatty acid of safflower, efficiently scavenged reactive oxygen species (Zahran et al., 2007), reduced MDA (Santos-Zago et al. 2007) and regulated lipid metabolism in various tissues by modulating lipid oxidation, lipolysis and de novo lipogenesis (Evans et al., 2002).

In conclusion, it could be observed that safflower herb itself has a hypolipidemic effect regardless of being $\gamma$-irradiated or not because the irradiation did not show significant variation compared to the nonirradiated herb. Therefore, supplementation of either raw or gamma irradiated safflower to hyper-lipedimic rats is effective in decreasing the oxidative stress by increasing the activity of antioxidant enzymes (CAT and SOD), nonenzymes; GSH and limiting lipid peroxidation process by reducing MDA level as well as ameliorating the hyper-lipidemia-induced change in the lipid profile and liver function.

\section{References}

Abdel-Khalek, H. H. (2008) Effect of gamma-irradiation on the microbial, chemical quality and biological activity of some spices and herbs. Ph. D. Thesis, fac. Agric. Cairo univ. Egypt.

Al-Kaisey, M. T., Mohammed, M. A., Alwan, A. K. H. and Mohammed, M. H. (2002) The effect of gamma irradiation on the viscosity of two barley cultivars for broiler chicks. Rad. Phys. Chem., 63, 295.

Allain,C., Poon, L., Chan, C., Richmond, W., and Fu, P. (1974) Enzymatic determination of total serum cholesterol. Clin. Chem., 20, 470.

Asp, M. L., Collene, A. L., Norris, L. E., Cole, R. M. and Stout, M. B. (2011) Timedependent effects of safflower oil to improve glycemia, inflammation and blood lipids in obese, post-menopausal women with type 2 diabetes: A randomized, double-masked, crossover study, Clin. Nutr., Under press..

Bergmeyer, H. U. J. and Grabe, M. (1987) The Method of Enzymatic analysis. 3rd edition. USA.PP273 VPS publishered.

Egypt. J. Rad. Sci. Applic., Vol. 24, No. 2 (2011) 
Barnes, S. (2010) The biochemistry, chemistry and physiology of the isoflavones in soybeans and their food products. Lymphat Res Biol., 8, 89.

Buettner, R., Scholmerich, J. and Bollheimer, L. C. ( 2007) High-fat diets: modeling the metabolic disorders of human obesity in rodents. Obesity, 5, 798.

Deladino, L., Anbinder, P. S., Navarro, A. S. and Martino, M. N. (2008) Encapsulation of natural antioxidants extracted from Ilex paraguariensis. Carbohydr. Polym., 71, 126.

Demacker, P. N., Vos-Janssen, H, E., Hifmans, A. G. M., Van't Laar, A. and Jansen, A. P. (1980) Measurement of high- density lipoprotein cholesterol in serum: Comparison of six isolation methods combined with enzymatic cholesterol analysis. Clin. Chem., 26, 1780.

Esendal, E., (2001) Safflower production and research in Turkey. Vth International Safflower Conference, Williston, North Dokota, Sidney, Montona, USA, July 23-27. 203-206.

Evans, M., Brown, J. and McIntosh, M. (2002) Isomer-specific effects of conjugated linoleic acid (CLA) on adiposity and lipid metabolism. J. Nutr. Biochem. 13, 508.

Fan, X. and Mastovska, K. (2006) Effectiveness of ionizing radiation in reducing furan and acrylamide levels in foods. J. Agric. Food Chem., 54, 8266.

Fossati, P. and Prencipe, L. (1982) Serum triglycerides determined calorimetrically with an enzyme that produce hydrogen peroxide. Clin. Chem., 28, 2077.

Friedewald, W. T., Levy, R. I. and Fredrickson, D. S. (1972) Estimation of the concentration of low-density lipoprotein cholesterol in plasma, without use of the preparative ultracentrifuge. Clin. Chem., 18, 499.

Frings, C. S., Frndley, T. W., Dunn, R. T. and Queen, C. A. (1972) Improved determination of total serum lipids by the sulfo-phospho-vanillin reaction. Clin. Chem., 18, 673.

Gotto, A. M. Jr., LaRosa, J. C., Hanninghake, D., Grundy, S. M., Wilson, P. W., Clarkson, T. B. and Hay, J. W. (1990) The cholesterol facts-A summary of the evidence relating dietary fats,serum cholesterol, and coronaryheart disease. Circulation, 81, 1721.

Gross, R., Bracci, R., Rudolph, N., Schroeder, E. and Kochen, J.A. (1967) Hydrogen peroxide toxicity and detoxification in the erythrocytes of new born infants, Blood, 29, 481.

Halliwell, B., Rafter, J. and Jenner, A. (2005) Health promotion by flavonoids, tocopherols, tocotrienols, and other phenols: direct or indirect effects? Antioxidant or not? Am. J. Clin. Nutr., 81, 268S.

Hamza, R. G. and Mahmoud, K. A. (2009) Effect of using Black cumin (Nigella sativa) as natural antioxidant on hyperlipidemia and antioxidant activities in senile rats. Isotope \& Rad. Res., 41, 521.

Egypt. J. Rad. Sci. Applic., Vol. 24, No. 2 (2011) 
Harnafi, H., Caid, H.S., Bouanani, N.H., Aziz, M. and Amrani, S. (2008) Hypolipemic activity of polyphenol-rich extracts from Ocimum basilicum in triton WR1339-induced hyperlipidemic mice. Food Chem., 108, 205.

Harris, W. S., Mozaffarian, D., Rimm, E., Kris-Etherton, P., Rudel, L. L. and Appel, L. J. (2009) Omega-6 fatty acids and risk for cardiovascular disease: a science advisory from the American Heart Association Nutrition Subcommittee of the Council on Nutrition, Physical Activity, and Metabolism; Council on Cardiovascular Nursing; and Council on Epidemiology and Prevention. Circulation, 119, 902.

Herrera, B. M., Keildson, S. and Lindgren, C. M. (2011) Genetics and epigenetics of obesity. Maturitas, 69, 41.

Ji, W. and Gong, B. Q. (2008) Hypolipidemic activity and mechanism of purified herbal extract of Salvia miltiorrhiza in hyperlipidemic rats. $J$. Ethnopharmacol., 119, 291.

Kim, E. O., Oh , J. H., Lee, S. K., Lee, J. Y. and Choi, S. W. ( 2007) Antioxidant properties and quantification of phenolic compounds from safflower (Carthamus tinctorius L.) seeds. Food Sci. Biotechnol., 16, 71.

Kind, P. and King, E. (1954) Estimation of plasma phosphatase by determination of hydrolysed phenol with aminoantipyrine. J. Clin. Pathol., 7, 322.

Kinsella, J. E. (1966) Metabolic patterns of the fatty acids of Periplanteta americana (L.) during its embryonic development. Can .J. Biochem., 44, 247.

Koyama, N., Kuribayashi, K., Seki, T., Kobayashi, K., Furuhata, Y., Suzuki, K., Arisaka, H., Nakano, T., Amino, Y. and Ishii, K. (2006) Serotonin derivatives, major safflower (Carthamus tinctorius L.) seed antioxidants, inhibit low-density lipoprotein (LDL) oxidation and atherosclerosis in apolipoprotein E-deficient mice. J. Agric. Food Chem., 54, 4970.

Lapenna, D., Del Boccio, G., Porreca, E., Pennelli, A., Mezzetti, A., De Gioia, S., Marzio, L., Di Ilio, C. and Cuccurullo, F. (1992) Effects of high-fat-, cholesterol-enriched diet on the antioxidant defence mechanisms in the rabbit heart. Free Radical. Res. Comm., 17, 87.

Lee, J. H., Kim, E. M., Chae, J. S., Jang, Y. S., Lee, J. H. and Lee, G. (2003) The effect of isoflavone supplement on plasma lipids and antioxidant status in hypercholesterolemic postmenopausal women. Korean J. Nutr., 36, 603.

Li, C., Xin-Bo, M., Yu-Hong, L., Shi-Cheng, P., Yi-Ping, F. and Min, W. (2011) Effects of persimmon leaf total flavonoid on enzyme of lipoprotein metabolism and antioxidation in hyperlipidemia rats. Chin. J. Natu. Med., 9, 74.

Lin, J. F., Lin, H. T. and Xie, L. Q. (2005) A review of chemical constituents, medicinal function, clinical application of persimmon leaves and their development and utilization. J. Food Ferment Ind., 31, 90.

Egypt. J. Rad. Sci. Applic., Vol. 24, No. 2 (2011) 
Minami, M. and Yoshikawa, H. (1979) A simplified assay method of superoxide dismutase. Clin. Chem. Acta., 92, 337.

Ming, M., Guanhua, L., Zhanhai, Y., Guang, C. and Xuan, Z. (2009) Effect of the Lycium barbarum polysaccharides administration on blood lipid metabolism and oxidative stress of mice fed high-fat diet in vivo. Food Chem., 113, 872.

Moon, K. D., Back, S. S., Kim, J. H., Jeon, S. M., Lee, M. K. and Choi, M. S. (2001) Safflower seed extract lowers plasma and hepatic lipids in rats fed highcholesterol diet. Nut. Res., 21, 895.

Norbert, W. T. (1995) Clinical Guide to Laboratory Tests, Third ed. Saunders W.B. Company, Philadelphia.

Oraei, M., Motalebi, A. A., Hoseini, E., Javan, S. and Hemmasi, A. H. (2011) Effect of Gamma Irradiation on Fatty Acid Composition of Rainbow Trout (Oncorhynchus mykiss) Fillets. Iran. J. Fisheries Sci., 10, 276.

Orhan, D. D., Orhan, N., Ergun, E. and Ergun, F. (2007) Hepatoprotective effect of Vitis vinifera L. leaves on carbon tetrachlorideinduced acute liver damage in rats. J. Ethnopharmacol., 112, 145.

Otunola, G. A., Oloyede, O. B., Oladiji, A. T. and Afolaya, A. A. ( 2010) Effects of diet-induced hypercholesterolemia on thelipid profile and some enzyme activities in female Wistar rats. Afric. J. Biochem. Res., 4, 149.

Reitman, S. and Frankel, S. (1957) A calorimetric method for the determination of serum glutamic oxalacetic and glutamic pyruvic transaminases. Am. J. Clin. Pathol., 28, 56.

Santos-Zago, L. F., Botelho, A. P. and de Oliveira, A. C. (2007) Supplementation with commercial mixtures of conjugated linoleic acid in association with vitamin $\mathrm{E}$ and the process of lipid autoxidation in rats. Lipids, 42, 845.

Shyamala, M. P., Paramundayil, J. J., Venukumar, M. R. and Latha, M. S. (2005) Probing the anti-hyperlipidemic efficacy of the allspice (Pimenta officinalis Lindl.) in rats fed with high fat diet. Ind. Physiol. Pharmacol., 49, 363.

Spady, D. K., Woolett, L. A. and Dietschy, J. M. (1993) Regulation of plasma LDLcholesterol levels by dietary cholesterol and fatty acids. Nutr, 13, 355.

SPSS (1998) Statistical Package for Social Science. Computer Software, Ver. 10. SPSS Company, London, UK.

Trinder, P. (1969) Determination of blood glucose using 4-amino phenazone as oxygen acceptor. J. Clin. Pathol., 22, 246.

Woods, S., Seeley, R., Rushing, P., D’Alessio, D. and Tso, P. (2002) A Controlled High-fat diet induces an obese syndrome in rats. J. Nutr., 133, 1081.

Yoshioka, T., Kawada, K., Shimada, T. and Mori, M. (1979) Lipid peroxidation in maternal and cord blood and protective mechanism against activated-oxygen toxicity in the blood. Am. J. Obstet. Gynecol., 135, 372.

Egypt. J. Rad. Sci. Applic., Vol. 24, No. 2 (2011) 
Younies, B. M. (2008) Effect of the aqueous extract of Cloves (Syzygium Aromaticum) on hyperlipidemia in senile rats. J. Rad. Res. Appl. Sci., $\mathbf{1}, 53$.

Zahran, A., Omaran, M., Mansour, S. and Ibrahim, N. (2007) Effectiveness of Carthamus tinctorius L. in the restitution of lipid composition in irradiated rats. Egypt. J. Rad. Sci. Appl., $20,75$.

Zhang, H., Tao, Y., Guo, J., Hu, Y. and Zheng-quan S. (2011) Hypolipidemic effects of chitosan nanoparticles in hyperlipidemia rats induced by high fat diet. Int. Immunopharmacol., 11, 457.

Zhao, G., Zheng, X., Gai, Y., Chu, W., Qin, G. and Guo, L. (2009) Safflower extracts functionally regulate monoamine transporters. J. Ethnopharmacol. 124, 116.

(Received: 05/04/2012;

accepted: 10/06/2012)

Egypt. J. Rad. Sci. Applic., Vol. 24, No. 2 (2011) 


\section{تحسين صورة الدهون ومضادات الأكسدة في الجرذان المصابة

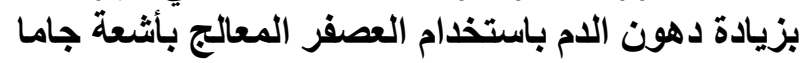

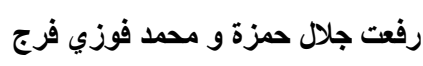

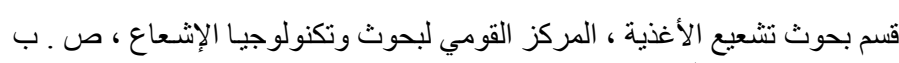

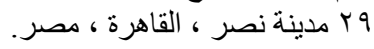

تعتبر زيادة دهون الدم من أحد الأسباب الضـارة التي تؤُدى إلى حدوث

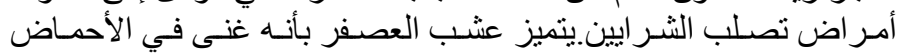

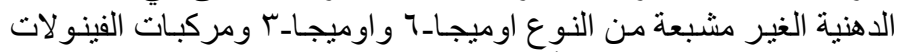

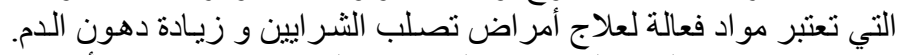

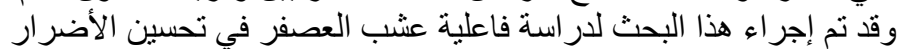

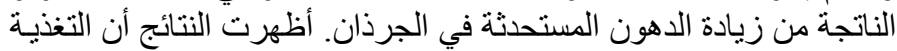

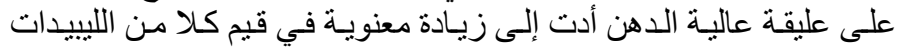

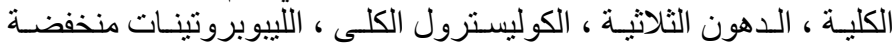

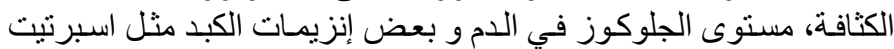

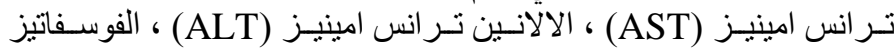

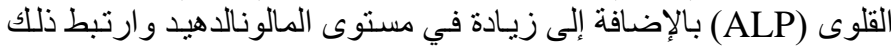

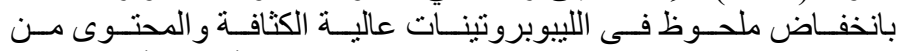

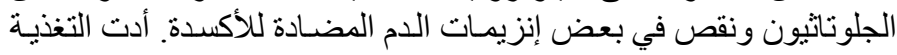

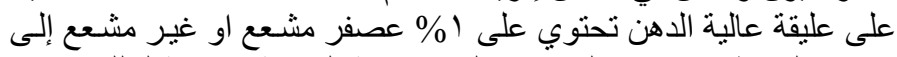

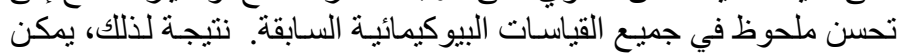

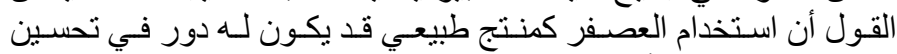

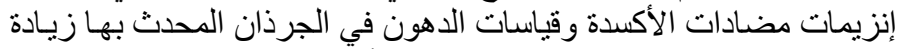

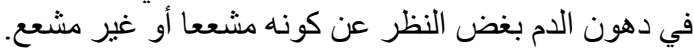

Egypt. J. Rad. Sci. Applic., Vol. 24, No. 2 (2011) 